\title{
A STUDY ON ELECTROLYTE CHANGES IN NEONATES RECEIVING PHOTOTHERAPY FOR NEONATAL HYPERBILIRUBINAEMIA
}

\author{
Pradeep Kumar Jena ${ }^{1}$, Mangal Charan Murmu², Tanusmita Bindhani ${ }^{3}$ \\ ${ }_{1}^{1}$ Associate Professor, Department of Paediatrics, SCB Medical College, Cuttack, Odisha, India. \\ ${ }^{2}$ Associate Professor, Department of Paediatrics, SCB Medical College, Cuttack, Odisha, India. \\ ${ }^{3}$ Resident Physician, Department of Paediatrics, SCB Medical College, Cuttack, Odisha, India.
}

\section{ABSTRACT}

\section{BACKGROUND}

Hyperbilirubinemia is the most common ailment requiring medical attention in newborns. Neonatal hyperbilirubinemia nearly affects $60 \%$ of term \& $80 \%$ of preterm neonates during the first week of life. Neonatal jaundice has much higher incidence in premature babies and often requires therapeutic intervention. Neonatal physiological jaundice could result either due to increased breakdown of foetal erythrocytes or low concentrations of hepatic glucuronyl transferase. Hypocalcaemia is one of the known adverse effects of phototherapy. $90 \%$ of the preterm and $75 \%$ of the full-term neonates develop hypocalcaemia post phototherapy. We intended to study the effects of photo therapy on serum electrolytes $\left(\mathrm{Na}^{+}, \mathrm{K}^{+}, \mathrm{Ca}^{++}\right)$.

\section{METHODS}

It is a prospective interventional study. Neonates who were born or admitted to 'Sardar Vallabhbhai Patel Postgraduate Institute of Pediatrics (SVP PG IP), Sriram Chandra Bhanja (SCB) Medical College and Hospital, Cuttack, Odisha, from October 1 st, 2016 to September $30^{\text {th }}, 2018$ receiving phototherapy for unconjugated hyperbilirubinemia after $24 \mathrm{hrs}$. of life without any co-morbidities were studied.

\section{RESULTS}

Serum calcium and serum sodium levels decrease with increasing duration of phototherapy. The comparative correlation between the preterm and term neonates considering the change in calcium level before and after phototherapy shows more change in values in term neonates.

\section{CONCLUSIONS}

Electrolyte changes are seen more commonly in pre-term neonates. The incidence of hypocalcemia was $22 \%$, it was $51.6 \%$ at $>48$ hrs. duration of phototherapy (PT) and $52.9 \%$ in preterm neonates. The incidence of hyponatremia was $10 \%$, it was $19.3 \%$ at $>48$ hrs. duration of PT and $29.4 \%$ in preterm neonates. The mean serum calcium levels before and after PT were $1.08 \pm 0.135 \mathrm{mmol} / \mathrm{L}$ and $1.008 \pm 0.161 \mathrm{mmol} / \mathrm{L}$ respectively.

\section{KEY WORDS}

Electrolytes, Phototherapy, Neonatal Hyperbilirubinemia

HOW TO CITE THIS ARTICLE: Jena PK, Murmu MC, Bindhani T. A study on electrolyte changes in neonates receiving phototherapy for neonatal hyperbilirubinaemia. J. Evolution Med. Dent. Sci. 2019;8(26):2105-2109, DOI: 10.14260/jemds/2019/463

\section{BACKGROUND}

Hyperbilirubinemia is the most common ailment requiring medical attention in newborns. Neonatal hyperbilirubinemia nearly affects $60 \%$ of term and $80 \%$ of preterm neonates during first week of life. 1 This is a normal physiologic phenomenon in most infants. However excessively elevated serum bilirubin can be detrimental as unconjugated bilirubin is neurotoxic ${ }^{2}$ and can cause residual neurologic sequelae or even death in some and hence is a cause for concern in pediatricians and family. ${ }^{3}$

Neonatal jaundice has much higher incidence in premature babies and often require therapeutic intervention. ${ }^{4}$ Neonatal physiologic jaundice could result

'Financial or Other Competing Interest': None.

Submission 19-04-2019, Peer Review 14-06-2019,

Acceptance 20-06-2019, Published 01-07-2019.

Corresponding Author:

Dr. Mangal Charan Murmu,

Department of Paediatrics,

SCB Medical College,

Cuttack, Odisha, India.

E-mail:mangal74murmu@yahoo.co.in

DOI: $10.14260 /$ jemds $/ 2019 / 463$ either due to increased breakdown of foetal erythrocytes or low concentrations of hepatic glucuronyl transferase.5,6 When additional factors like immune or non-immune hemolytic anemia, polycythemia, several metabolic and endocrine disorders accompany the basic mechanisms pathologic neonatal jaundice ensues.

Incidence of neonatal jaundice is higher in eastern world. Various genetic influences are known to increase the incidence, especially mutations/polymorphisms in the genes that code for enzymes and proteins involved in bilirubin metabolism. ${ }^{7}$ Recent data suggests a correlation between higher levels of epidermal growth factors both in breast milk and infants with neonatal jaundice. ${ }^{8}$ Incidence is also higher in premature infants, infants with low birth weight, infants of mothers with diabetes and congenital infections.

Main treatment modalities in neonatal jaundice are Phototherapy, exchange transfusion and intravenous immune globulin. Phototherapy is the primary treatment in neonates with unconjugated hyperbilirubinemia. ${ }^{9}$ Phototherapy isomerizes the bilirubin into water-soluble forms by photo oxidation, configurational isomerization, and structural isomerization. These photo isomers of bilirubin are excreted in bile and urine thereby reducing the serum bilirubin levels. 
Adverse effects of phototherapy include feed intolerance, loose stools, bronze baby syndrome, hypocalcaemia etc. ${ }^{10}$

Although many studies were carried out, to depict the other side effects those relating to dyselectrolytemia have been few, especially those relating to serum sodium and potassium. Hypocalcaemia is one of the known adverse effects. $90 \%$ of the preterm and $75 \%$ of the full term neonates develop hypocalcaemia post phototherapy. ${ }^{11}$ We intended to study the effects of photo therapy on serum electrolytes $\left(\mathrm{Na}^{+}\right.$, $\mathrm{K}^{+}, \mathrm{Ca}^{++}$).

\section{Aims and Objectives}

1. To study the electrolyte changes in neonates receiving phototherapy for neonatal jaundice at Sardar Vallabhbhai Patel Postgraduate Institute of Pediatric (SVP PG IP), SCB Medical College and Hospital, Cuttack, Odisha.

2. To assess the effect of Phototherapy on Serum Sodium, Serum Potassium and Serum Calcium levels.

\section{METHODS}

It is a prospective interventional study. After obtaining clearance from institutional ethical committee the study was conducted. Neonates who were born or admitted to 'SVP PG IP,S C B Medical College and Hospital,' Cuttack, Odisha from October $1^{\text {st }} 2016$ to September 30th 2018, receiving Light Emitting Diode(LED) phototherapy for unconjugated hyperbilirubinemia after 24 hrs. of life without any comorbidities were studied. All the investigation was done in the central laboratory of S C B Medical College and SVP PG Institute of Pediatrics, Cuttack.

\section{Inclusion Criteria}

Neonates receiving phototherapy for unconjugated hyperbilirubinemia after 24 hrs. of life without any comorbidities were included in the study.

\section{Exclusion Criteria}

1. Neonates with evidence of Hemolysis.

2. Onset of jaundice $<24$ hrs. \& received exchange transfusion.

3. Neonates with Conjugated Hyperbilirubinemia.

4. Neonates who receive I.V. fluid and intensive care.

5. Neonates with formula feeding

6. Neonates with co-morbidities like birth asphyxia, septicaemia, acute renal failure and others.

7. Abnormal electrolyte status detected Pre phototherapy.

\section{Study Protocol}

Patients were randomly selected following the inclusion and exclusion criteria. The Phototherapy was administered as per standard American Association of Pediatrics (AAP) guidelines. Electrolytes were checked at 0 hour (First sample) and at 48 hours of phototherapy or at discontinuation of phototherapy (Second sample) whichever is earlier. The first sample was considered as control. Comparative study was made between these two samples groups to determine the changes in electrolytes. The blood tests were run on the collected samples and data tabulated. Serum electrolytes $(\mathrm{Na}+\mathrm{K}+$ and $\mathrm{Ca} 2+)$ were estimated using auto analyzer which employs 'ion selective electrode' for estimation. By Diazo method Serum bilirubin was estimated. A total of 100 neonates (including 56 males and 44 females) including both term and preterm were studied. The data obtained were tabulated and analyzed by proper statistical method.

\section{RESULTS}

\begin{tabular}{|c|c|c|c|}
\hline \multirow{2}{*}{ Weight (KG) } & \multicolumn{2}{|c|}{ Gender } & \multirow{2}{*}{ Total (\%) } \\
\cline { 2 - 3 } & Male & Female & \\
\hline LBW $(<2.5$ Kgs. $)$ & $11(19.6 \%)$ & $12(27.2 \%)$ & $23(23 \%)$ \\
\hline Normal & $45(80.4 \%)$ & $32(72.8 \%)$ & $77(77 \%)$ \\
\hline Total & $\mathbf{5 6}$ & $\mathbf{4 4}$ & $\mathbf{1 0 0}$ \\
\hline Table 1. Incidence of Neonatal Hyperbilirubinemia with \\
Respect to Birth Weight \\
\hline
\end{tabular}

\begin{tabular}{|c|c|c|c|}
\hline \multirow{2}{*}{$\begin{array}{c}\text { Gestational Age } \\
\text { (Weeks) }\end{array}$} & Male & Female & \multirow{2}{*}{ Total } \\
\cline { 2 - 4 } & $8(14.3 \%)$ & $9(20.5 \%)$ & $17(17 \%)$ \\
\hline 37 to 40 & $46(82.1 \%)$ & $34(77.3 \%)$ & $80(80 \%)$ \\
\hline$>40$ & $2(3.6 \%)$ & $1(2.2 \%)$ & $3(3 \%)$ \\
\hline Total & $\mathbf{5 6 ( 1 0 0 \% )}$ & $\mathbf{4 4}(\mathbf{1 0 0} \%)$ & $\mathbf{1 0 0}(\mathbf{1 0 0} \%)$ \\
\hline Table 2. Incidence of Neonatal Hyperbilirubinemia with Respect to \\
Gestational Age \\
\hline $\begin{array}{l}\text { Mean gestational age is 37.22 } \pm 2.01 \text { wks. contingency coefficient } 0.0870, \\
\mathrm{p}=0.6828\end{array}$
\end{tabular}

\begin{tabular}{|c|c|c|c|c|c|}
\hline \multirow{2}{*}{ Calcium } & \multicolumn{3}{|c|}{ Duration of PT } & \multirow{2}{*}{ Total } & \multirow{2}{*}{ p Value } \\
\cline { 2 - 5 } & $<\mathbf{2 4}$ hrs & $\mathbf{2 4 - 4 8}$ hrs & $\mathbf{> 4 8}$ hrs & \\
\hline$<1 \mathrm{mmol} / \mathrm{L}$ & $0(0 \%)$ & $5(7.7 \%)$ & $17(51.6 \%)$ & $22(22 \%)$ & $<0.0001$ \\
\hline $1-1.23 \mathrm{mmol} / \mathrm{L}$ & $4(100 \%)$ & $60(92.3 \%)$ & $15(48.4 \%)$ & $78(78 \%)$ & \\
\hline$>1.23 \mathrm{mmol} / \mathrm{L}$ & 0 & 0 & 0 & 0 & \\
\hline Table 3. Comparison Between Pre-Phototherapy and \\
Post-Phototherapy Serum Calcium with Respect to Duration of \\
Phototherapy \\
\hline
\end{tabular}

\begin{tabular}{|c|c|c|c|c|c|}
\hline \multirow{2}{*}{$\begin{array}{c}\text { Serum } \\
\text { (Ionic) } \\
\text { Calcium }\end{array}$} & \multicolumn{3}{|c|}{ Gestational Age } & \multirow[b]{2}{*}{ Total } & \multirow{5}{*}{$\begin{array}{r}\text { p Value } \\
0.0113\end{array}$} \\
\hline & $<37$ (17) & 37 to $40(80)$ & $>40$ (3) & & \\
\hline$<1 \mathrm{mmol} / \mathrm{L}$ & $9(52.9 \%)$ & $12(15 \%)$ & $1(33.3 \%)$ & $22(22 \%)$ & \\
\hline $1-.23 \mathrm{mmol} / \mathrm{L}$ & $8(47.1 \%)$ & $60(85 \%)$ & $2(66.7 \%)$ & $78(78 \%)$ & \\
\hline$>1.23 \mathrm{mmol} / \mathrm{L}$ & 0 & 0 & 0 & 0 & \\
\hline \multicolumn{6}{|c|}{$\begin{array}{l}\text { Table 4. Comparison Between Pre-Phototherapy and Post- } \\
\text { Phototherapy Serum Calcium with Respect to Gestational Age }\end{array}$} \\
\hline
\end{tabular}

\begin{tabular}{|c|c|c|c|c|c|}
\hline \multirow[b]{2}{*}{$\begin{array}{l}\text { Serum } \\
\text { Sodium }\end{array}$} & \multicolumn{3}{|c|}{ Duration of PT } & \multirow{2}{*}{\begin{tabular}{c|} 
Total \\
100
\end{tabular}} & \multirow{5}{*}{$\begin{array}{c}\text { p } \\
\text { Value } \\
0.0167\end{array}$} \\
\hline & $\begin{array}{c}<24 \text { hrs. } \\
\text { (4) }\end{array}$ & $\begin{array}{c}\text { 24-48 hrs. } \\
\text { (65) }\end{array}$ & $\begin{array}{c}>48 \text { hrs. } \\
\text { (31) }\end{array}$ & & \\
\hline$<135 \mathrm{mmol} / \mathrm{L}$ & 0 & $4(6.2 \%)$ & $6(19.3 \%)$ & $10(10 \%)$ & \\
\hline $\begin{array}{l}135-145 \\
\mathrm{mmol} / \mathrm{L}\end{array}$ & $4(100 \%)$ & $61(93.8 \%)$ & $22(70.9 \%)$ & $87(87 \%)$ & \\
\hline$>145 \mathrm{mmol} / \mathrm{L}$ & 0 & 0 & $3(9.6 \%)$ & $3(3 \%)$ & \\
\hline \multicolumn{6}{|c|}{$\begin{array}{c}\text { Table 5. Comparison Between Pre-Phototherapy and } \\
\text { Post-Phototherapy Serum Sodium with Respect to Duration of } \\
\text { Phototherapy }\end{array}$} \\
\hline
\end{tabular}

\begin{tabular}{|c|c|c|c|c|c|}
\hline \multirow[b]{2}{*}{$\begin{array}{l}\text { Serum } \\
\text { Sodium }\end{array}$} & \multicolumn{3}{|c|}{ Gestational Age } & \multirow[t]{2}{*}{ Total } & \multirow{5}{*}{$\begin{array}{c}\text { p Value } \\
0.0204\end{array}$} \\
\hline & $\begin{array}{c}<37 \\
\text { Weeks (17) }\end{array}$ & $\begin{array}{c}37 \text { to } 40 \\
\text { Weeks }(80)\end{array}$ & $\begin{array}{c}>40 \\
\text { Weeks (3) }\end{array}$ & & \\
\hline $\begin{array}{c}<135 \\
\mathrm{mmol} / \mathrm{L}\end{array}$ & $5(29.4 \%)$ & $4(5 \%)$ & $1(33.3 \%)$ & $10(10 \%)$ & \\
\hline $\begin{array}{l}135-145 \\
\mathrm{mmol} / \mathrm{L}\end{array}$ & $12(70.6 \%)$ & $73(91.2 \%)$ & $2(66.7 \%)$ & $87(87 \%)$ & \\
\hline $\begin{array}{c}>145 \\
\mathrm{mmol} / \mathrm{L}\end{array}$ & 0 & $3(3.8 \%)$ & 0 & $3(3 \%)$ & \\
\hline
\end{tabular}

Table 6. Comparison Between Pre-Phototherapy and Post Phototherapy Serum Sodium with Respect to Gestational Age 


\begin{tabular}{|c|c|c|c|c|c|}
\hline \multirow{2}{*}{$\begin{array}{c}\text { Serum } \\
\text { Potassium }\end{array}$} & \multicolumn{3}{|c|}{ Duration of PT } & Total & \\
\cline { 2 - 5 }$<3.5 \mathrm{mmol} / \mathrm{L}$ & $0(0 \%)$ & 0 & $1(3.2 \%)$ & $1(1 \%)$ & p Value \\
& 0.3375 \\
\hline $3.5-5.5 \mathrm{mmol} / \mathrm{L}$ & $4(100 \%)$ & $65(100 \%)$ & $29(93.6 \%)$ & $98(97 \%)$ \\
\hline$>5.5 \mathrm{mmol} / \mathrm{L}$ & $0(0 \%)$ & 0 & $1(3.2 \%)$ & $21(2 \%)$ & \\
\hline Table 7. Comparison Between Pre-Phototherapy and \\
Post-Phototherapy Serum Potassium with Respect to \\
Duration of Phototherapy \\
\hline
\end{tabular}

\begin{tabular}{|c|c|c|c|c|c|}
\hline \multirow[b]{2}{*}{$\begin{array}{c}\text { Serum } \\
\text { Potassium }\end{array}$} & \multicolumn{3}{|c|}{ Gestational Age } & \multirow[t]{2}{*}{ Total } & \multirow{5}{*}{\begin{tabular}{|c|}
$\mathbf{p}$ Value \\
0.248
\end{tabular}} \\
\hline & $\begin{array}{c}<37 \\
\text { weeks } \\
(17)\end{array}$ & \begin{tabular}{|c|}
37 to 40 \\
weeks $(80)$
\end{tabular} & $\begin{array}{c}>40 \text { weeks } \\
\text { (3) }\end{array}$ & & \\
\hline$<3.5 \mathrm{mmol} / \mathrm{L}$ & $1(5.9 \%)$ & 0 & 0 & $1(1 \%)$ & \\
\hline $3.5-5.5 \mathrm{mmol} / \mathrm{L}$ & $16(94.1 \%)$ & $78(97.5 \%)$ & $3(100 \%)$ & $97(97 \%)$ & \\
\hline \begin{tabular}{|l|}
$>5.5 \mathrm{mmol} / \mathrm{L}$ \\
\end{tabular} & 0 & $2(2.5 \%)$ & 0 & $2(2 \%)$ & \\
\hline
\end{tabular}

\begin{tabular}{|c|c|c|c|c|c|}
\hline & Pre & Post & Difference & t Value & p Value \\
\hline Ionic Calcium & $1.08 \pm 0.14$ & $1.007 \pm 0.16$ & 0.07 & 4.536 & $<0.0001$ \\
\hline Sodium & $139.1 \pm 2.7$ & $137.6 \pm 2.8$ & 1.5 & 5.56 & $<0.0001$ \\
\hline Potassium & $4.4 \pm 0.5$ & $4.5 \pm 0.5$ & -0.1 & 2.00 & 0.05 \\
\hline \multicolumn{7}{|c|}{ Table 9. Conclusive Comparative Evaluation of Pre and } \\
Post-Phototherapy Serum Electrolytes \\
\hline
\end{tabular}

\section{Principles of Biochemical Tests}

SERUM Na+, K+ and Ca2+ (86) - Ion Selective Electrode: An ion-selective electrode (ISE), also known as a specific ion electrode (SIE), is a transducer (or sensor) that converts the activity of a specific ion dissolved in a solution into an electrical potential. The voltage is theoretically dependent on the logarithm of the ionic activity, according to the Nernst equation. Ion-selective electrodes are used in analytical chemistry and biochemical/biophysical research, where measurements of ionic concentration in an aqueous solution are required. Serum Bilirubin - Diazo.

Ehrlich's diazo reagent reacts with the direct bilirubin in the serum to form a pink to reddish-purple colored compound (Azobilirubin) read at one minute.

\section{Data Analysis}

All the statistical analysis was done using Windows Excel, IBM SPSS 24 software, Med Calc 9.0.1 and Systat 12.0. To assess the association of different parameters Pearson's ChiSquare test was used. Differences were considered statistically significant if $p<0.05$, very significant if $p<0.01$ and very highly significant if $\mathrm{p}<0.001$.

In our study incidence of low birth weight babies was $23 \%$, mean birth weight was $2.61 \pm 0.38 \mathrm{Kgs}$. In our study we found out that among low birth weight (LBW) neonates, incidence of females was more than males. However, it was not statistically significant.

In our study group, the incidence of preterm babies was $17 \%$ compared to $80 \%$ in $37-40$ wks. gestational age and $3 \%$ in $>40$ wks gestational age group. The mean gestational age in the study group was $37.22 \pm 2.01$ weeks.

The Incidence of hypocalcaemia was $51.6 \%$ when duration of phototherapy was $>48 \mathrm{hrs}$. as compared to $7.7 \%$ when the duration was between 24-48 hrs. Thus, it infers that babies were at higher risk of hypocalcaemia if kept under phototherapy for more than $48 \mathrm{hrs}$. chi-square test revealed the $\mathrm{p}$ value obtained was $<0.0001$. Thus, it is considered to be statistically significant.
The Incidence of hypocalcaemia following phototherapy was more in preterm neonates $(52.9 \%)$ than in term neonates (15\%). Thus, it infers that preterm babies were at more risk of hypocalcaemia following phototherapy than term babies. By chi-square test, using test for paired sample means, the $p$ value obtained was $<0.05$. Thus, it is considered to be statistically significant.

The Incidence of hyponatremia was $19.3 \%$ when duration of phototherapy was $>48 \mathrm{hrs}$. as compared to $6.2 \%$ when the duration was between 24-48 hrs. Thus, it infers that babies were at higher risk of hyponatremia if kept under phototherapy for more than $48 \mathrm{hrs}$. Chi-square test revealed the $\mathrm{p}$ value obtained was 0.0167 . Thus, it is considered to be statistically significant.

The Incidence of hyponatremia following phototherapy was more in preterm neonates $(29.4 \%)$ than in term neonates (5\%). Thus, it infers that preterm babies were at more risk of hyponatremia following phototherapy than term babies. By chi-square test the $\mathrm{p}$ value obtained was $<0.05$. Thus, it is considered to be statistically significant.

The Incidence of hypokalaemia was $3.2 \%$ when duration of phototherapy was $>48 \mathrm{hrs}$. Thus, it infers that babies were at higher risk of hypokalaemia if kept under phototherapy for more than 48 hrs. However, Chi-square test revealed that the $\mathrm{p}$ value was 0.3375 . Thus, it is considered to be statistically insignificant.

The Incidence of hypokalaemia following phototherapy was more in preterm neonates (5.9\%) than in term neonates. Thus, it infers that preterm babies were at more risk of hypokalaemia following phototherapy than term babies. By chi-square test the $p$ value obtained was 0.226 . Thus, it is considered to be statistically insignificant.

Overall, there was a significant decline in serum calcium and serum sodium values post phototherapy.

\section{DISCUSSION}

Decreasing serum electrolytes is one of the known complications of phototherapy. While hypocalcaemia has been well documented to be associated with phototherapy effects of phototherapy on other major serum electrolytes has been meagrely studied. Our study studied the effects of phototherapy on major serum electrolytes in neonates being treated for hyperbilirubinemia and noted statistically significant results. The present study included a total of 100 neonates 35 weeks. Term gestation was considered to be more than and equal to 37 weeks' gestation and those $<37$ weeks' gestation age were considered to be pre term. Karamifar et $\mathrm{al}^{12} 2002$ selected pre terms more than 31 weeks whereas Eghbalian et $\mathrm{al}^{13}$ (2002) included only term neonates. Arora et $\mathrm{al}^{14}$ (2014) included 46 preterm and 54 term neonates. All the term and preterm neonates in the present study were appropriate for gestational age. Same was the case in the studies done by Romagnoli et $\mathrm{al}^{15}$ (1979), Sethi el al ${ }^{16}$ (1993), and Arora et $\mathrm{al}^{14}$ (2014).

\section{Comparison of Mean Birth Weight with Other Studies}

Mean birth weight of our study group members is $1.94 \mathrm{Kgs} \pm$ 140 grams in pre-term vs $2.73 \mathrm{Kg} \pm 275$ grams in term neonates. These results match Jain el al (18) study in which mean birth weight in preterm vs term were $2150 \pm 150$ grams vs $2800 \pm 220$ grams and Karamifar et al $^{12} 2077 \pm 316$ grams Vs $2889 \pm 474$ grams respectively. 


\section{Comparison of Duration of Phototherapy}

In our study the mean duration of phototherapy was $40 \pm 9.7$ hrs. Mean duration of phototherapy in a similar study conducted by Eghbalian et $\mathrm{al}^{13}$ was 3 days. This could be because of larger sample size and more sample of preterm neonates in their study.

\section{Comparison of Hypocalcaemia Incidence with Other Studies}

In our study we found out that 9 preterm and 13 term/post term cases were found to have hypocalcaemia. They amount to $52.9 \%$ and $15.6 \%$ of incidence respectively. The relation was found to be statistically significant with a $p$ value of 0.011. the significant fall in serum calcium level in preterm and term babies after phototherapy was in correlation with study by Karamifer et al. ${ }^{12}$ The trends and significance levels in our study are in correlation with similar studies by Yadav RK et al, ${ }^{17}$ Arora et al ${ }^{14}$ and Reddy et al. ${ }^{18}$

Sethi et $\mathrm{al}^{16}$ study has shown that $90 \%$ of Preterm neonates and $75 \%$ of full-term neonates treated with phototherapy developed hypocalcaemia.

Jain et $\mathrm{al}^{19}$ have found that $55 \%$ of preterm neonates and $30 \%$ of full-term neonates developed hypocalcaemia after phototherapy. This study is in correlation with our study. Jain et al have found that $55 \%$ of preterm neonates and $30 \%$ of full-term neonates developed hypocalcaemia after phototherapy. This study is in correlation with our study.

\section{Comparison of Mean Serum Calcium Levels Before and} After Phototherapy in Preterm Neonates

In our study the mean serum ionic calcium level before and after phototherapy in preterm neonates was $0.89 \pm 0.2$ $\mathrm{mmol} / \mathrm{L}$ and $0.92 \pm 0.2 \mathrm{mmol} / \mathrm{dl}$ respectively and it was statistically significant. This was similar to study done by Karamifar et al. ${ }^{12}$

Comparison of mean serum calcium levels before and after phototherapy in term neonates.

In our study the mean serum calcium level before and after phototherapy in preterm neonates was $1.12 \pm 0.06$ $\mathrm{mmol} / \mathrm{L}$ and $1.02 \pm 0.14 \mathrm{mmol} / \mathrm{L}$ respectively and it was statistically significant. This was similar to study done by Karamifar et $\mathrm{al}^{12}$ and Reddy AK et al. ${ }^{18}$

\section{Hyponatremia}

There are very few studies regarding phototherapy induced other electrolyte changes. The differential effect of other electrolytes with phototherapy has not been studied by other workers except that for Curtis MD et $\mathrm{al}^{20}$ (1981) study which stated that absorption of water, sodium chloride, and potassium was significantly impaired in the patients receiving phototherapy. Incidence of hyponatremia in our study group was $10 \%$ and found to be higher in $<37$ wks. group and LBW babies than in $>37$ wks. group and normal weight babies. Mean serum sodium levels were significantly decreased after phototherapy. As the $\mathrm{P}$ value $<0.05$, this difference is considered to be statistically significant.

\section{Hypokalaemia}

There were no significant potassium changes in our study. Tan KL et $\mathrm{al}^{21}$ (1981) study in healthy full-term neonates demonstrated a transient raise in potassium levels after phototherapy which was in contrast to our study. It is evident that in the present study phototherapy induced hypocalcaemia and hyponatremia was more in preterm and LBW babies but the actual relationship in these babies with phototherapy has to be evaluated with larger sample studies for estimation of the incidence as the metabolic side effects are more common in preterm and LBW babies.

\section{CONCLUSIONS}

Serum calcium and serum sodium levels decrease with increasing duration of phototherapy. These electrolyte changes are seen more frequently in pre-term neonates. The comparative correlation between the preterm and term neonates considering the change in calcium level before and after phototherapy shows more change in values in term neonates. A total of 100 neonates (including 56 males and 44 females) including both term and preterm were studied. The mean birth weight was $2.61 \pm 0.38 \mathrm{Kgs}$. mean gestational age was $37.22 \pm 2.01$ weeks. The incidence of hypocalcaemia was $22 \%$, it was $51.6 \%$ at $>48 \mathrm{hrs}$. duration of PT and $52.9 \%$ in preterm neonates. The incidence of hyponatremia was $10 \%$, it was $19.3 \%$ at $>48 \mathrm{hrs}$. duration of PT and $29.4 \%$ in preterm neonates. The mean serum calcium levels before and after PT were $1.08 \pm 0.135 \mathrm{mmol} / \mathrm{L}$ and $1.008 \pm 0.161 \mathrm{mmol} / \mathrm{L}$ respectively. The mean serum sodium levels before and after PT were $139.1 \pm 2.7$ and $137.6 \pm 2.8$.

\section{REFERENCES}

[1] Watchko JF. Hyperbilirubinemia in African American neonates: clinical issues and current challenges. Semin Foetal Neonatal Med 2010;15(3):176-82.

[2] Shapiro SM. Bilirubin toxicity in the developing nervous system. Pediatr Neurol 2003;29(5):410-21.

[3] Maisels MJ, Kring E. Length of stay, jaundice and hospital readmission. Pediatrics 1998;101(6):995-8.

[4] Kaini NR, Chaudhary D, Adhikary V, et al. Overview of cases and prevalence of jaundice in neonatal intensive care unit. Nepal Med Coll J 2006;8(2):133-5.

[5] Huang MJ, Kua KE, Teng HC, et al. Risk factors for severe hyperbilirubinemia in neonates. Pediatr Res 2004;56(5):682-9.

[6] Christensen RD, Yaish HM, Lemons RS. Neonatal hemolytic jaundice: morphologic features of erythrocytes that will help you diagnose the underlying condition. Neonatology 2014;105(4):2439.

[7] Hua L, Shi D, Bishop PR, et al. The role of UGT1A1*28 mutation in jaundiced infants with hypertrophic pyloric stenosis. Pediatr Res 2005;58(5):881-4.

[8] Kumral A, Ozkan H, Duman N, et al. Breast milk jaundice correlates with high levels of epidermal growth factor. Pediatr Res 2009;66(2):218-21.

[9] Woodgate P, Jardine LA. Neonatal jaundice. BMJ Clin Evid 2011;2011. pii: 0319.

[10] Maisels MJ. Neonatal Jaundice. Pediatr Rev 2006;27(12):443-54.

[11] Narayan S, Aggarwal R, Upadhyay A, et al. Survival and morbidity in extremely low birth weight (ELBW) infants. Indian Pediatr 2003;40(2):130-5.

[12] Karamifar H, Pishva N, Amirhakimi GH. Prevalence of phototherapy induced hypocalcemia. Iran J Med Sci 2002;27(4):166-8. 
[13] Eghbalian F, Monsef A. Phototherapy-induced hypocalcemia in icteric newborn. Iran J Med Sci 2002;27(4):169-71.

[14] Arora S, Narang GS, Singh G. Serum calcium levels in preterm and term neonates on phototherapy. J Nepal Paediatr Soc 2014;34(1):24-8.

[15] Romangnoli C, Polidori G, Cataidl L, et al. Phototherapy induced hypocalcemia. J Pediatr 1979;94(5):815-16.

[16] Sethi H, Saili A, Dutta AK. Phototherapy induced hypocalcemia. Indian Pediatr 1993;30(12):1403-6.

[17] Yadav RK, Sethi RS, Sethi AS, et al. The evaluation of effect of phototherapy on serum calcium level. People's J Sci Res 2012;5(2):1-4.
[18] Reddy AT, Bai KV, Shankar SU. Electrolyte changes following phototherapy in neonatal hyperbilirubinemia. Int J Sci Res 2015;4(7):752-8.

[19] Jain BK, Singh H, Sigh D, et al. Phototherapy induced hypocalcemia. Indian Pediatr 1998;35(6):566-7.

[20] Curtis-Cohen M, Stahl GE, Costarino AT, et al. Randomized trial of prophylactic phototherapy in the infant with very low birth weight. J Pediatr 1985;107(1):121-4.

[21] Tan KL. Efficacy of bidirectional fiber-optic phototherapy for neonatal hyperbilirubinemia. Pediatrics 1997;99(5):E13. 